\title{
STRATEGI PENGEMBANGAN PARIWISATA DALAM PENINGKATAN PENDAPATAN ASLI DAERAH (PAD) KOTA TERNATE PROVINSI MALUKU UTARA
}

\author{
Oleh \\ Aswir Pratama, \\ Kusworo, Bayi Priyono \\ 1) Institut Pemerintahan Dalam Negeri \\ Program Magister Terapan Studi Pemerintahan Daerah Institut Pemerintahan Dalam Negeri \\ aswirpratama@22gmail.com \\ ${ }^{2,3)}$ Institut Pemerintahan Dalam Negeri
}

\begin{abstract}
TOURISM DEVELOPMENT STRATEGY IN INCREASING THE ORIGINAL REVENUE INCOME FOR TERNATE CITY, NORTH MALUKU PROVINCE

The focus of this study is to determine the tourism development carried out by the Ternate City

1 Tourism Office, the factors that influence and determine the strategy that should be carried out for tourism development in Ternate. This study uses theories from Oka A. Yoeti related to tourism development and SWOT analysis and litmus test to determine the right strategy. This research uses a qualitative method with a descriptive approach. In collecting data, researchers conducted observations, interviews and collected documents about tourism development carried out by the Department of Tourism, as well as its contribution to the Regional Original Revenue of Ternate City.

The results showed that the development of tourism in the context of increasing Local Revenue has not been implemented optimally. The existence of tourism development and its contribution related to Local Revenue, but have not been able to reach the target. Besides the lack of attractions, facilities and infrastructure, which causes a lack of attractiveness in attractions that are managed by the government. The influencing factors consist of internal and external factors which then proceed with determining the strategies that should be carried out for success based on the SWOT analysis and litmus test found very strategic issues including: Optimizing the functions and programs of the Department of Tourism in tourism development, optimizing the functions and programs The Department of Tourism in the development of tourism, improving supporting facilities and infrastructure on tourist objects managed by the government, seeking the legality of public areas or new attractions to be managed by local governments.
\end{abstract}

Keywords: strategy, development, tourism

\footnotetext{
AbSTRAK

Gokus dari penelitian ini adalah untuk mengetahui pengembangan pariwisata yang C dilaksanakan oleh Dinas Pariwisata Kota Ternate, faktor-faktor yang memengaruhi serta menentukan strategi yang sebaiknya dilakukan untuk pengembangan pariwisata di Kota Ternate. Penelitian ini menggunakan teori dari Oka A. Yoeti terkait pengembangan
} 
pariwisata serta melakukan analisis SWOT dan litmus test untuk menentukan strategi yang tepat. Penelitian ini menggunakan metode kualitatif dengan pendekatan deskriptif. Dalam mengumpulkan data, peneliti melakukan observasi, wawancara dan mengumpulkan dokumen tentang pengembangan pariwisata yang dilakukan oleh Dinas Pariwisata, serta kontribusinya terhadap Pendapatan Asli Daerah (PAD) Kota Ternate.

Hasil penelitian menunjukkan bahwa pengembangan pariwisata dalam rangka peningkatan Pendapatan Asli Daerah (PAD) belum terlaksana secara optimal. Adanya pengembangan pariwisata serta kontribusinya terkait Pendapatan Asli Daerah (PAD), akan tetapi belum mampu mencapai target. Selain itu minimnya atraksi, sarana dan prasarana, yang menyebabkan kurangnya daya tarik pada objek wisata yang dikelola oleh pemerintah. Faktor-faktor yang memengaruhi terdiri dari faktor internal dan faktor eksternal yang kemudian dilanjutkan dengan menentukan strategi yang sebaiknya dilakukan untuk keberhasilan berdasarkan analisis SWOT dan litmus test didapatkan isu sangat strategis antara lain: Mengoptimalkan fungsi dan program Dinas Pariwisata dalam pengembangan pariwisata, mengoptimalkan fungsi dan program Dinas Pariwisata dalam pengembangan pariwisata, meningkatkan sarana dan prasarana pendukung pada objek wisata yang dikelola pemerintah, mengupayakan legalitas area publik atau objek wisata baru untuk dikelola oleh pemerintah daerah.

Kata kunci: strategi, pengembangan, pariwisata

\section{PENDAHULUAN}

$\mathrm{P}$ endapatan Asli Daerah (PAD) merupakan pendapatan yang diperoleh daerah tersebut dari sumber daya yang dimilikinya sendiri. Pendapatan Asli Daerah (PAD) antara lain berasal dari pajak daerah, retribusi daerah, hasil pengelolaan kekayaan daerah yang dipisahkan, serta lain-lain pendapatan asli daerah yang sah. Penjelasan Pasal 285 dalam Undang-Undang No. 23 Tahun 2014 tentang Pemerintahan Daerah menyebutkan bahwa pengelolaan kekayaan daerah yang dipisahkan dapat berupa hasil kerja sama dengan pihak ketiga atau bagian laba dari pendapatan Badan Usaha Milik Daerah (BUMD). Sedangkan lain-lain pendapatan asli daerah yang sah meliputi pendapatan asli daerah di luar retribusi daerah dan pajak daerah termasuk di antara jasa giro dan hasil penjualan aset daerah.

Pariwisata juga merupakan salah satu sektor pembangunan yang saat ini sedang digencarkan oleh pemerintah. Hal ini dikarenakan pariwisata memiliki peran yang sangat besar dalam pembangunan Indonesia khususnya sebagai penghasil devisa negara.
Tujuan pengembangan pariwisata di Indonesia dapat dilihat dengan jelas dalam Instruksi Presiden Republik Indonesia No. 9 Tahun 1969 tentang "Pedoman Pembinaan Pengembangan Kepariwisataan Nasional”, khususnya Bab II Pasal 3, yang menyatakan bahwa usaha-usaha pengembangan pariwisata di Indonesiabersifat suatu pembangunan "industri pariwisata" dan merupakan bagian dari usaha pengembangan dan pembangunan serta kesejahteraan untuk masyarakat dan negara. Industri pariwisata dikembangkan di Indonesia juga bertujuan untuk mendatangkan dan meningkatkan devisa Negara selain dari sektor nonmigas. Para pakar ekonomi memperkirakan sektor pariwisata akan menjadi salah satu kegiatan ekonomi yang penting pada abad ke-21.

Pembangunan pariwisata adalah pembangunan yang bersifat multidimensional yang artinya melibatkan berbagai sektor pembangunan yaitu sektor ekonomi, hukum, politik, sosial, dan budaya. Keberhasilan pembangunan secanggih apa pun rencana dan strateginya tetapi tanpa dukungan oleh sektor pembangunan lainnya maka mustahil jika akan berhasil.

Kota Ternate adalah salah satu kota di Provinsi Maluku Utara yang merupakan 
salah satu waterfront city di Indonesia yang awalnya dikenal dalam sejarah dunia sebagai pusat perdagangan rempah-rempah skala internasional pada abad ke-15 yang lalu. Selama menjadi kota madya, Ternate telah menunjukkan perkembangan sebagai kota perdagangan dan industri serta kemajuan yang cukup pesat dalam penyelenggaraan pemerintahan, pelaksanaan pembangunan, dan pelayanan kepada masyarakat. Di sisi lain, Kota Ternate dihadapkan dengan kondisi geografis wilayah yang merupakan sebuah gunung api aktif dengan kemiringan lereng terbesar di atas empat puluh persen yang mengerucut ke arah puncak gunung dan dikelilingi laut. Hal ini berdampak pada ketersediaan lahan untuk dapat dikembangkan sebagai ruang publik kota.

Dengan demikian, wilayah pesisir menjadi salah satu alternatif strategis dalam pengembangan kawasan, khususnya dalam pemenuhan infrastruktur perkotaan dengan metode reklamasi pantai. Kawasan timur Indonesia sangat dikenal memiliki kekayaan alam yang sangat berlimpah, termasuk juga rempah-rempah. Ternate sebagai salah satu kota yang berada di timur Indonesia memiliki kekayaan alam yang berlimpah. Kondisi ini merupakan salah satu daya tarik bagi bangsa asing seperti Portugis dan Belanda untuk melakukan penjajahan di Maluku Utara khususnya Ternate.

Namun yang terjadi di lapangan adalah dengan banyaknya sumber daya alam dan potensi wisata yang ada di Maluku Utara khususnya Kota Ternate, seharusnya mampu untuk mendongkrak Pendapatan Asli Daerah (PAD) yang ada, akan tetapi hal ini belum mampu mendongkrak secara signifikan Pendapatan Asli Daerah yang ada di Kota Ternate dan Maluku Utara pada umumnya.

Sarana dan prasarana menjadi salah satu faktor yang masih belum mampu untuk dipenuhi agar terwujudnya kenyamanan serta kemudahan bagi wisatawan untuk menikmati pariwisata yang ada di kota
Ternate. Sebagai contoh pada salah satu objek wisata yaitu pantai Sulamadaha, akses angkutan umum untuk menuju ke lokasi pantai masih terbatas, selain itu ketersediaan air bersih dan pengelolaan di lokasi objek wisata seperti toilet umum, sistem keamanan dan tempat untuk parkir bagi wisatawan juga masih terbatas. Terbatasnya sarana pendukung di tempat wisata juga terdapat pada objek pariwisata Danau Tolire, pada objek wisata ini hanya terdapat warung yang disediakan warga setempat berupa jajanan makanan dan minuman, akan tetapi untuk toilet masih belum tersedia, sehingga wisatawan harus mencari toilet yang berada di luar lokasi objek wisata.

Pendapatan Asli Daerah di Kota Ternate dalam tiga tahun terakhir tidak pernah mencapai target, hal ini sebagaimana yang dituturkan dalam wawancara dengan Legislator Ternate, Mubin A. Wahid, di Kantor Dewan Perwakilan Rakyat Daerah (DPRD) Kota Ternate:

Kami telah mengingatkan kepada pemerintah Kota Ternate terutama Wali kota, bahwa dalam tiga tahun terakhir PAD tidak pernah capai target dan harus dilakukan evaluasi terhadap kinerja SKPD, menurutnya Wali kota harus memberikan penyegaran pada OPD pengelola PAD agar pungut retribusi atau pajak lebih bijak, jikalau mereka tidak mampu melakukan penyegaran lebih baik melakukan rolling agar bisa bertanggung jawab dalam mengurus retribusi. ${ }^{1}$

Sebagai perbandingan pada 2019 target dari Pendapatan Asli Daerah (PAD) Kota Ternate sebesar 153 Miliar sementara sampai memasuki Oktober 2019 realisasi dari target tersebut adalah sebesar 96 Miliar. Sementara pada 2018 Pendapatan Asli Daerah (PAD) Kota Ternate yang awalnya ditargetkan mencapai 153 Miliar, hanya

1 ambon.antaranews.com (Diakses pada 21-12-2019 pukul 11.30) 
mampu tercapai 59 Miliar, atau sekitar 31\% dari target yang ditentukan. ${ }^{2}$ Sementara perbandingan dengan Tahun 2017, Sampai memasuki November 2017 dari target 89 miliar dapat tercapai 70 Miliar atau sekitar 78\% dari target yang ditentukan. Meskipun pada 2019 terjadi peningkatan dari tahun sebelumnya, akan tetapi dapat dilihat bahwa tahun 2018 terjadi penurunan daripada Tahun 2017.

Selanjutnya, kontribusi yang diberikan dari sektor pariwisata selama ini ternyata belum mampu mendongkrak secara signifikan Pendapatan Asli Daerah Kota Ternate, hal ini dapat dilihat dari tabel berikut : ${ }^{3}$

Tabel 1 Kontribusi sektor pariwisata terhadap PAD Kota Ternate 2016-2018

\begin{tabular}{cccl}
\hline No & Tahun & $\begin{array}{c}\text { PAD } \\
\text { Kota Ternate }\end{array}$ & $\begin{array}{c}\text { Kontribusi } \\
\text { Sektor Pariwisata }\end{array}$ \\
\hline 1 & 2016 & Rp70, 8 Miliar & Rp310 Juta \\
2 & 2017 & Rp59, 3 Miliar & Rp411 Juta \\
3 & 2018 & Rp96, 4 Miliar & Rp405 Juta \\
\hline
\end{tabular}

Dari tabel di atas dapat dilihat kontribusi dari sektor pariwisata yang diperoleh pada 2016 - 2018 di mana pada tiga tahun tersebut kontribusi sektor pariwisata selalu berada di bawah angka 500 Juta. Persentase kontribusi sektor pariwisata di bawah 5 $\%$ untuk periode tahun tersebut sehingga dapat dikatakan bahwa kontribusi dari sektor Pariwisata terhadap Pendapatan Asli Daerah (PAD) masih rendah.

\section{KAJIAN PUSTAKA}

\section{Teori Manajemen Strategi}

Menurut Pearce dan Robinson sebagaimana dikutip dalam Sedarmayanti

2 https//:indotimur.com,00 PAD-Ternate (Diakses pada 19-12-2019 pukul 20.00)

3 ambon.antaranews.com,00 anggaran-pengembangan-pariwisata-ternate (Diakses pada 20-12-2019 pukul 10.00)
(2013:22), "manajemen strategis merupakan kumpulan keputusan dan tindakan yang menghasilkan perumusan dan penerapan strategi didesain untuk mencapai sasaran organisasi". Manajemen strategi merupakan proses atau rangkaian kegiatan pengambilan keputusan yang bersifat mendasar dan menyeluruh disertai penetapan cara melaksanakannya yang dibuat oleh pimpinan dan diimplementasikan oleh seluruh jajaran di dalam sebuah organisasi untuk mencapai tujuan dari organisasi tersebut.

Kegunaan manajemen strategis adalah untuk melakukan tindakan pada saat sekarang demi masa depan serta menjadi wahana untuk bertindak mengintegrasikan dan melembagakan mekanisme untuk berubah. Manajemen strategis biasanya dihubungkandenganpendekatanmanajemen yang integratif yang mengedepankan secara bersama-sama seluruh elemen seperti planning, implementing dan controlling dari strategi bisnis. Dengan kata lain, manajemen strategis meliputi formulasi strategis dan implementasi strategis. Seperti yang diungkapkan Hunger dan Wheelen (2009: 9) bahwa, "proses manajemen strategis meliputi empat elemen dasar yaitu pengamatan lingkungan, perumusan strategi, implementasi strategi serta evaluasi dan pengendalian".

Menurut Chandler dalam Rangkuti (2016: 3) menyatakan bahwa "strategi merupakan alat untuk mencapai tujuan perusahaan dalam kaitannya dengan jangka panjang, program tindak lanjut, serta prioritas alokasi sumber daya". Sedangkan menurut Porter dalam Rangkuti (2016:04) mengemukakan bahwa "strategi adalah alat yang sangat penting untuk mencapai keunggulan bersaing".

\section{Teori Pariwisata}

Menurut UU No. 10 Tahun 2009 tentang Kepariwisataan, bahwa kepariwisataan merupakan bagian integral dari pembangunan nasional yang dilakukan 
secara sistematis, terencana, terpadu, berkelanjutan, dan bertanggung jawab dengan tetap memberikan perlindungan terhadap nilai-nilai agama, budaya yang hidup dalam masyarakat, kelestarian dan mutu lingkungan hidup, serta kepentingan sosial.

Pariwisata itu motif kegiatannya adalah untuk mengisi waktu luang, untuk bersenangsenang, bersantai, studi, kegiatan Agama, dan mungkin kegiatan olahraga. Selain itu semua kegiatan tersebut dapat memberikan keuntungan bagi pelakunya baik secara fisik maupun psikis, baik untuk sementara waktu maupun dalam jangka waktu yang lama. Kepariwisataan dipandang sebagai sesuatu yang abstrak, misalnya saja sebagai suatu gejala yang melukiskan kepergian orangorang di dalam negerinya sendiri (pariwisata domestik), atau penyeberangan orang-orang pada tapal batas suatu negara (pariwisata internasional) Isdarmanto (2017: 4).

\section{Teori Pengembangan Pariwisata}

Pengembangan merupakan suatu proses usaha menuju ke arah yang lebih baik, dalam hal ini dapat berarti adanya pertumbuhan dan perubahan. Perubahan yang dimaksud bisa dalam segi kuantitas maupun kualitasnya. Sunaryo (2013: 168) menyatakan dalam mengembangkan sebuah destinasi wisata, seorang perencana paling tidak harus memperhatikan dua lingkup pengembangan, yaitu lingkup spasial dan tingkat pengembangan dari destinasi tersebut. Dalam proses pelaksanaan tugas dan fungsi serta perannya, dalam hal pengembangan objek pariwisata daerah, pemerintah daerah perlu melakukan suatu upaya dalam pengembangan sarana dan prasarana yang berkaitan dengan kepariwisataan. Pola dalam proses pengembangan jaringan kawasan pariwisata memerlukan kerja sama misalnya kerja sama yang dilakukan oleh pemerintah daerah dengan pihak swasta secara sinergis dan berkelanjutan.
Menurut Pitana dan Diarta (2009: 134) Pengembangan pariwisata memerlukan teknik perencanaan yang baik dan tepat. Teknik pengembangan itu harus menggabungkan beberapa aspek penunjang kesuksesan pariwisata, Aspek-aspek tersebut adalah aspek aksesibiliti (transportasi dan saluran pemasaran), karakteristik infrastruktur pariwisata, tingkat interaksi sosial, keterkaitan/kompatibilitas dengan sektor lain, daya tahan akan dampak pariwisata, tingkat resistensi komunikasi lokal dan seterusnya.

Pengembangan pariwisata dapat memperbesar keuntungan serta dapat memperkecil masalah-masalah yang ada baik masalah internal maupun masalah eksternal. Perkembangan kawasan pariwisata dikatakan berkembang tergantung apa yang menjadi daya tarik atau yang ditawarkan dari kawasan pariwisata tersebut kepada wisatawan. Suatu objek wisata dikatakan berkembang juga tidak terlepas dari 3A, yaitu attraction (atraksi), accessibility (mudah dicapai), aminities (fasilitas) Sunaryo (2013: 133).

\section{Teori Destinasi Pariwisata}

Destinasi adalah suatu tempat yang dikunjungi oleh manusia dalam kurun waktu yang relatif lama dalam suatu perjalanan dibandingkan dengan tempat lain yang dilalui selama perjalanan. Tuohino dan Konu (2014) menyatakan bahwa pengertian dari destinasi adalah area geografis sebagai lokasi yang dapat menarik wisatawan untuk tinggal secara sementara yang terdiri dari berbagai produk pariwisata, sehingga membutuhkan berbagai prasyarat untuk merealisasikannya.

Menurut Undang-Undang No. 10 Tahun 2009 Pasal 1 ayat (6) Destinasi Pariwisata adalah kawasan geografis yang berada dalam satu atau lebih wilayah administratif fasilitas umum, fasilitas pariwisata, aksesibilitas, serta masyarakat yang saling terkait 
melengkapi terwujudnya pariwisata. Pitana (2009: 126) menjelaskan bahwa: "Destinasi merupakan suatu tempat yang dikunjungi dengan waktu yang signifikan selama perjalanan seseorang dibandingkan dengan tempat lain yang dilalui selama perjalanan".

Selanjutnya, Kusudianto dalam Pitana (2009: 126) mengemukakan bahwa destinasi wisata dapat digolongkan atau dikelompokkan berdasarkan ciri-ciri sebagai berikut.

1. Destinasi sumber daya alam, seperti iklim, pantai, hutan

2. Destinasi sumber daya budaya, seperti tempat bersejarah, museum, teater, dan masyarakat lokal.

3. Fasilitas rekreasi seperti taman hiburan.

4. Event seperti pesta kesenian Bali, pasar malam.

5. Aktivitas spesifik, seperti wisata belanja

6. Daya tarik psikologis, seperti petualangan, perjalanan $\mathrm{dsb}$.

\section{Undang-Undang No. 23 Tahun 2014} tentang Pemerintahan Daerah

Pada Undang-Undang No. 23 Tahun 2014 tentang Pemerintahan Daerah Telah dijelaskan dalam ayat (1) menyatakan, urusan Pemerintahan terdiri atas urusan pemerintahan absolut, urusan pemerintahan konkuren, dan urusan pemerintahan umum. Di mana, salah satu dari urusan yang berkaitan dengan pariwisata merupakan urusan pemerintahan pilihan.

Sebagaimana diamanatkan dalam Pasal 12 ayat (3) huruf b Undang-Undang No. 23 Tahun 2014 tentang Pemerintahan Daerah, bahwa urusan kelautan, pariwisata, pertanian, kehutanan, energi, perdagangan, perindustrian dan transmigrasi merupakan urusan pemerintahan pilihan. Sehingga, pemerintah pusat dan daerah wajib memberikan bantuan dalam proses pengembangan kawasan pariwisata.

\section{Undang-Undang No. 10 Tahun 2009 tentang Kepariwisataan}

Pada Undang-Undang No. 10 Tahun 2009 tentang Kepariwisataan Pasal 1 ayat (4) dijelaskan arti dari kepariwisataan itu sendiri yang menyatakan. Kepariwisataan yaitu serangkaian suatu kegiatan yang dilakukan, serta berkaitan dengan proses pariwisata yang multidimensi serta multidisiplin yang muncul sebagai perwujudan dari suatu kebutuhan setiap orang dan negara, serta interaksi antara wisatawan yang berkunjung dan masyarakat setempat baik sesama wisatawan, pemerintah daerah maupun pengusaha (pengelola).

Pada Undang-Undang No. 10 Tahun 2009 tentang Kepariwisataan Pasal 3 dijelaskan tentang fungsi dan tujuan kepariwisataan. Kepariwisataan berfungsi memenuhi kebutuhan rohani, jasmani dan intelektual setiap wisatawan dengan rekreasi dan perjalanan serta dapat meningkatkan pendapatan suatu negara untuk mewujudkan kesejahteraan rakyat.

Berdasarkan dengan Undang-Undang No. 10 Tahun 2009 tentang Kepariwisataan, maka dapat penulis simpulkan yaitu harus memenuhi dan berdasarkan asas-asas yang telah diuraikan diatas. Pembangunan kepariwisataan dilakukan atas dasar rencana induk pembangunan kepariwisataan baik tingkat Nasional, Provinsi, dan Kabupaten/Kota yang diatur dalam peraturan daerah tingkat Provinsi/Kabupaten/ Kota. Di mana penyusunan rencana induk pembangunan kepariwisataan melibatkan para pemangku kepentingan (stakeholder) dan meliputi perencanaan pembangunan industri wisata, destinasi wisata, pemasaran dan kelembagaan kepariwisataan.

\section{METODE PENELITIAN}

Dalam penelitian ini, berdasarkan analisisnya penulis menggunakan metode deskriptif dengan mengkombinasikannya dengan metode kualitatif. Pendekatan yang dilakukan oleh penulis pada saat penyusunan 
penelitian ini adalah pendekatan induktif, yakni pendekatan yang dilakukan dengan melihat fakta di lapangan, yakni kejadian yang sebenarnya selanjutnya dapat digunakan penulis sebagai bahan untuk menjawab dan memecahkan focus penelitian yang dilakukan, Hal ini disebabkan karena permasalahan yang belum jelas, holistik, kompleks, dinamis dan penuh makna. Untuk memperoleh datadata yang diperlukan dalam melakukan penelitian ini, maka teknik pengumpulan data yang digunakan oleh penulis pada penelitian ini yaitu wawancara (interview), observasi nonpartisipan dan dokumentasi.

Setelah melakukan analisis terhadap faktor Internal dan eksternal, selanjutnya dilakukan perumusan isu-isu strategis dengan menggunakan matriks SWOT. Matriks ini dapat menggambarkan secara jelas bagaimana faktor eksternal (peluang dan ancaman) yang dihadapi organisasi dapat disesuaikan dengan faktor internal organisasi (kekuatan dan kelemahan). Selanjutnya, maka akan didapatkan isu-isu strategis yang dianggap paling penting serta bagaimana strategi yang diambil dalam pemecahan masalah tersebut. Sehingga hasil penelitian ini dapat digunakan dalam pengembangan pariwisata dalam peningkatan PAD Kota Ternate Provinsi Maluku Utara.

\section{HASIL PENELITIAN}

\section{Pelaksanaan Pengembangan Pari- wisata di Kota Ternate}

Dalam rangka membahas pelaksanaan pengembangan pariwisata (tourism development) di Kota Ternate, konsep yang digunakan oleh penulis yaitu berdasarkan teori yang dikemukakan oleh Yoeti. Di mana dijelaskan bahwa terdapat lima hal yang akan dianalisis, yaitu wisatawan, transportasi, atraksi, fasilitas, dan promosi. Kemudian untuk menentukan Strategi yang tepat penulis menggunakan konsep SWOT (strength, weakness, opportunities, dan threats), yang dikemukakan oleh Bryson.

\section{- Wisatawan}

Wisatawan dapat menjadi salah satu tolak ukur dalam keberhasilan pengembangan pariwisata, sehingga dapat dikatakan bahwasanya wisatawan adalah faktor penting dalam pengembangan pariwisata. Wisatawan sendiri terdiri dari wisatawan domestik yaitu wisatawan yang berasal dari dalam negeri itu sendiri dan wisatawan mancanegara yaitu warga negara asing yang mengadakan perjalanan wisata memasuki negara lain.

Antusiasme wisatawan yang datang berkunjung ke Kota Ternate dapat dikatakan cukup tinggi, karena persentase kedatangan pada 2019 mencapai sampai lebih dari 90\% baik itu wisatawan domestik maupun wisatawan lokal, hal ini menunjukkan bahwa memang objek wisata yang ada di Ternate sudah mampu menarik pengunjung untuk dapat berwisata di Ternate. Hal demikian pun berlaku dalam kurun waktu tiga tahun terakhir di mana kunjungan wisatawan mancanegara. Bahkan pada dua tahun sebelumnya melewati target yang dibuat oleh Dinas Pariwisata itu sendiri.

Sementara itu, antusiasme wisatawan yang berkunjung ke Kota Ternate di dominasi oleh wisatawan domestik, namun dapat dilihat juga bahwasanya antara 2017 s.d. 2019 terjadi penurunan jumlah wisatawan yang datang. Hal ini secara tidak langsung berdampak kepada kontribusi Pariwisata terhadap Pendapatan Asli Daerah (PAD), sebagaimana diketahui bahwa wisatawan merupakan salah satu dimensi pengembangan pariwisata sehingga apabila jumlah wisatawan yang datang berkunjung banyak maka akan berpengaruh terhadap Pendapatan Asli Daerah tersebut.

\section{- Transportasi}

Transportasi adalah suatu proses pemindahan atau pengangkutan manusia, hewan, serta barang, dari suatu tempat menuju tempat lain dengan menggunakan 
alat transportasi. Salah satu faktor berkembangnya pariwisata adalah dengan adanya akses transportasi yang memudahkan wisatawan untuk dapat melakukan perjalanan menuju ke sebuah daerah wisata, sehingga untuk mencapai hal tersebut ketersediaan transportasi baik darat, udara, maupun laut/air harus dimiliki oleh sebuah daerah wisata.

Transportasi baik darat, laut/air, maupun udara sudah ada di Kota Ternate dan sudah diupayakan pemerintah untuk dapat mempermudah wisatawan dalam melakukan perjalanan baik menuju ke Ternate maupun mobilisasi ketika sudah berada di Ternate untuk menikmati beberapa objek wisata yang ada di Kota Ternate. Sehingga peneliti dapat menyimpulkan bahwa untuk faktor transportasi dalam upaya pengembangan pariwisata di Kota Ternate sudah baik.

\section{- Atraksi}

Atraksi wisata adalah daya tarik dari suatu objek pariwisata ataupun hasil kesenian suatu daerah tertentu yang dapat menarik wisatawan/turis asing untuk berkunjung menuju ke tempat wisata tersebut. $^{4}$

Sejauh ini pemerintah sedang mengupayakan agar di lokasi-lokasi wisata yang ada di Ternate memiliki atraksi untuk dapat dinikmati oleh wisatawan, selama ini sudah ada namun masih belum optimal karena seperti contohnya apabila wisatawan datang ke salah satu objek wisata yang dikelola oleh pemerintah yaitu Batuangus, maka di sana hanya dapat menikmati keindahan alam saja dan wisatawan hanya melakukan foto, sementara untuk di lokasi lainnya seperti di Pantai Sulamadaha maka wisatawan hanya melakukan aktivitas seperti berenang dan membeli jajanan ringan.

4 (https://www.pengertianmenurutparaahli.net/ pengertian-atraksi/14 mei 2020/10.00)
Sementara itu, diketahui bahwa pemerintah sedang mengupayakan untuk mengajak komunitas-komunitas budaya yang ada di Ternate untuk bersama-sama dalam berpartisipasi mengenalkan wisata dan budaya secara bersamaan, dengan melakukan atraksi seperti tarian-tarian atau kegiatan lainnya namun dilakukan di lokasi atau objek wisata, sehingga wisatawan yang datang selain menikmati aktivitas wisata juga sekaligus mendapatkan edukasi budaya yang ada di Ternate.

\section{- Fasilitas}

$\begin{array}{clrr}\text { Menurut } & \text { Suryo } & \text { Subroto fasilitas } \\ \text { merupakan } & \text { segala } & \text { sesuatu } & \text { yang }\end{array}$ dapat memberikan kemudahan dan memperlancar pelaksanaan suatu usaha yang dapat berupa benda maupun uang. Pendapat Suryo memperjelas bahwa fasilitas dapat berbentuk uang maupun barang yang dapat dimanfaatkan. ${ }^{5}$ Dalam Bidang pariwisata, fasilitas merupakan salah satu hal yang sangat penting untuk dimiliki oleh sebuah kawasan wisata dalam mendukung pengembangan wisata di daerah tersebut.

Mengacu pada teori yang penulis gunakan pada penelitian ini yaitu bahwa fasilitas yang dimaksud di sini adalah sarana dan prasarana yang menunjang kegiatan kepariwisataan. Sarana adalah alat yang dapat digunakan untuk melancarkan atau memudahkan manusia dalam mencapai tujuan tertentu, sarana berhubungan langsung dan menjadi penunjang utama dalam suatu aktivitas. Sarana dapat berbentuk benda bergerak dan/atau tidak bergerak. Sementara prasarana adalah segala sesuatu yang menunjang secara langsung maupun tidak langsung segala jenis sarana, umumnya prasarana dimiliki dan dibangun oleh pemerintah dalam bentuk benda tidak bergerak.

5 (https://dosenppkn.com/pengertian-fasilitas/diakses pada 12 Mei 2020/10.30) 
Sarana prasarana untuk objek wisata yang dikelola oleh Pemerintah Daerah Kota Ternate melalui Dinas Pariwisata sudah pernah dilakukan sebelumnya, namun belum secara menyeluruh di bangun di ketiga objek wisata yang dikelola Pemerintah, yakni di Danau Tolire, Pantai Sulamadaha, dan di Batuangus, serta kondisi sarana dan prasarana yang sudah ada beberapa di antaranya kondisinya sudah kurang terawat sehingga perlu diperbaharui lagi agar wisatawan yang berkunjung dapat merasakan kenyamanan ketika melakukan aktivitas wisata

\section{- Informasi dan Promosi}

Pengertian Informasiadalah sekumpulan data atau fakta yang telah diproses dan diolah sedemikian rupa sehingga menghasilkan sesuatu yang bisa dipahami dan memberikan manfaat bagi penerimanya. Data dan fakta adalah "bahan baku" informasi, tetapi tidak semuanya bisa diolah menjadi informasi.

Berdasarkan wawancara yang peneliti lakukan maka dapat diketahui bahwa sudah ada upaya yang dilakukan mempromosikan pariwisata yang dilakukan oleh Dinas Pariwisata Kota Ternate, selain itu juga dengan mengadakan acara atau event yang bekerja sama dengan pihak komunitas seperti komunitas sepeda yang dibuatkan jalur ke objek pariwisata sehingga masyarakat lebih paham lagi serta memiliki minat untuk mengunjungi lokasi wisata, selain itu dengan adanya pemanfaatan kemajuan teknologi seperti pembangunan Ternate Information Center (TIC) di dua lokasi yaitu Bandara dan landmark Ternate, serta pembuatan website Dinas Pariwisata dan melalui media sosial sehingga masyarakat baik dari dalam Ternate itu sendiri ataupun wisatawan dari luar Ternate dapat dengan mudah mendapatkan informasi terkait objek wisata serta akses yang dapat digunakan untuk menuju ke Lokasi wisata tersebut. Sehingga dapat peneliti simpulkan untuk informasi dan promosi sudah cukup baik hal ini dapat menjadi salah satu peluang untuk pengembangan pariwisata.

\section{Kontribusi Pariwisata terhadap Pendapatan Asli Daerah (PAD)}

Perkembangan industri pariwisata dapat memberikan peluang terhadap pertumbuhan ekonomi nasional maupun regional secara otomatis akan dapat berdampak pada penerimaan PAD. Maka peranan pemerintah sebagai fasilitator sangat strategis dalam mewujudkan upaya-upaya ke arah pengembangan pariwisata tersebut melalui kepemimpinan institusinya dalam hal perencanaan (planning) daerah kawasan pariwisata, pembangunan (development) fasilitas utama dan pendukung pariwisata, pengeluaran kebijakan (policy) pariwisata, dan pembuatan dan penegakan peraturan (regulation), sehingga pariwisata daerah mendapat perhatian lebih mendalam khususnya pada aset-aset wisata yang memiliki potensi wisata yang bukan saja bernilai historis melainkan aset wisata yang berpotensi ekonomis.

Dalam memacu pertumbuhan ekonomi serta peningkatan kesempatan kerja, maka industri pariwisata dijadikan salah satu sektor yang harus diperhitungkan dengan mengoptimalkan pendayagunaan potensi yang dimiliki dengan melihat efektivitas hasil pelaksanaan dan penyelenggaraan yang sesuai dengan ketetapan visi, misi dan sasaran organisasi. Dinas Pariwisata Kota Ternate memiliki fungsi yang cukup strategis dalam mewujudkan upaya - upaya dalam pengembangan pariwisata. Dengan tidak mengabaikan azas kepariwisataan dan memperhatikan keanekaragaman, keunikan dan kekhasan budaya daerah dan alam serta kebutuhan para stakeholdernya.

Salah satu misi dari Wali Kota Ternate adalah 'Membangun Kota Ternate sebagai Pusat Destinasi Wisata Unggulan Berbasis Budaya Sejarah dan Bahari", yang kemudian Dinas Pariwisata diberikan tugas untuk menjabarkan misi tersebut, sehingga 
perlu ditetapkan tujuan dan sasaran Dinas Pariwisata Kota Ternate. Tujuan yang ditetapkan adalah "Mewujudkan Kota Ternate sebagai destinasi wisata wisman dan wisnus".

Untuk mendukung dan mewujudkan tujuan tersebut maka dirumuskanlah sasaran utama (strategis) di mana salah satu di antaranya adalah Jumlah Pendapatan Asli Daerah (PAD) Ternate sektor pariwisata.

\section{Faktor Internal}

\section{Kekuatan (Strengths)}

a. Peraturan Daerah Kota Ternate yang mengatur tentang rencana induk pengembangan pariwisata Kota Ternate;

b. Adanya program-program yang dilakukan oleh Dinas Pariwisata Kota Ternate untuk mengembangkan pariwisata;

c. Adanya Komitmen Dinas Pariwisata untuk mengembangkan pariwisata

\section{Kelemahan (weakness)}

Terbatasnya sarana dan prasarana pendukung yang ada di objek wisata yang dikelola oleh pemerintah daerah;

a. Kompetensi sumber daya aparatur yang belum memadai dalam pengembangan pariwisata;

b. Masih kurangnya atraksi pada objek wisata yang dikelola oleh pemerintah;

c. Rendahnya kesadaran masyarakat untuk berpartisipasi dalam pengembangan pariwisata.

\section{Faktor Eksternal}

\section{Peluang (Opportunities)}

a. Adanya kerja sama dengan pihak ketiga dalam pengembangan pariwisata seperti kerja sama dengan bandara dan komunitaskomunitas budaya; b. Tersedianya akses transportasi untuk menuju ke Ternate dan objek wisata di Kota Ternate baik transportasi darat, laut, dan udara;

c. Adanya pemberdayaan masyarakat sekitar objek wisata yang dikelola oleh pemerintah daerah dengan menyediakan tempat warung makan tanpa dipungut retribusi oleh pemerintah;

d. Pemanfaatan teknologi sebagai sarana untuk mempromosikan dan mempermudah akses informasi terhadap pariwisata dengan pembangunan Ternate Information Center (TIC), serta media sosial dan website.

\section{Ancaman (Threats)}

a. Kurangnya kesadaran masyarakat untuk ikut dalam pemeliharaan terhadap objek wisata maupun sarana dan prasarana wisata yang dikelola oleh pemerintah;

b. Kondisi geografis Kota Ternate;

c. Banyaknya area publik dan objek wisata baru;

d. Masih minimnya daya tarik objek wisata yang dikelola oleh pemerintah.

\section{Strategi yang Sebaiknya Digunakan}

Berdasarkan perhitungan dengan menggunakanujilitmus,makadapatdiketahui untuk strategi yang dapat digunakan untuk keberhasilan pengembangan pariwisata dalam meningkatkan Pendapatan Asli Daerah (PAD) Kota Ternate Provinsi Maluku Utara yaitu sebagai berikut.

1. Isu sangat strategis, meliputi:

a. Mengoptimalkan fungsi dan program Dinas Pariwisata dalam pengembangan pariwisata;

b. Mengoptimalkan fungsi dan program Dinas Pariwisata dalam pengembangan pariwisata; 
c. Meningkatkan sarana dan prasarana pendukung pada objek wisata yang dikelola pemerintah;

d. Mengupayakan legalitas area publik atau objek wisata baru untuk dikelola oleh pemerintah daerah.

2. Isu cukup strategis, meliputi:

a. Meningkatkan pemanfaatan teknologi dalam mempromosikan dan memberikan informasi pariwisata;

b. Mengajak masyarakat sekitar objek wisata untuk menampilkan atraksi di objek wisata;

c. Meningkatkan kapasitas aparatur dalam pengembangan pariwisata;

d. Membuat program untuk memberikan edukasi dan sosialisasi kepada masyarakat akan pentingnya aset pariwisata bagi daerah;

e. Memaksimalkan daya tarik pada objek wisata yang dikelola oleh pemerintah dan menambahkan atraksi baru pada objek wisata agar wisatawan tertarik untuk berkunjung.

\section{SIMPULAN}

Berdasarkan hasil penelitian dan pembahasan yang dilakukan oleh peneliti, maka peneliti dapat menyimpulkan bahwa:

1. Pelaksanaan pengembangan pariwisata yang dilakukan oleh Dinas Pariwisata Kota Ternate Provinsi Maluku Utara apabila ditinjau dariteoriyang digunakan yaitu teori pengembangan pariwisata dari Oka A. Yoeti, pada indikator wisatawan antusiasme untuk datang berwisata ke Ternate cukup Tinggi, hal ini juga didukung dengan adanya akses transportasi di Kota Ternate yang mana transportasi juga merupakan salah satu indikator dalam pengembangan pariwisata. Indikator Informasi dan Promosi juga merupakan salah satu aspek yang cukup baik dilaksanakan oleh Dinas Pariwisata Kota Ternate karena telah memanfaatkan teknologi serta melaksanakan event atau acara dan melibatkan juga dengan komunitas masyarakat. Hal yang masih kurang yang peneliti temukan di lapangan adalah pada dua indikator pengembangan pariwisata yang belum berjalan dengan baik yaitu Atraksi dan fasilitas yang perlu untuk dilakukan peningkatan agar dapat mengembangkan pariwisata yang ada di Kota Ternate.

2. Faktor-faktor yang memengaruhi pengembangan pariwisata dalam peningkatan Pendapat Asli Daerah Kota Ternate Provinsi Maluku Utara. Pertama, adalah Faktor Internal, meliputi:

(a) Peraturan Daerah Kota Ternate yang mengatur tentang rencana induk pengembangan pariwisata Kota Ternate

(b) Adanya program-program yang dilakukan oleh Dinas Pariwisata Kota Ternate untuk mengembangkan pariwisata

(c) Adanya Komitmen Dinas Pariwisata untuk mengembangkan pariwisata

(d) Terbatasnya sarana dan prasarana pendukung yang ada di objek wisata yang dikelola oleh pemerintah daerah

(e) Kompetensi sumber daya aparatur yang belum memadai dalam pengembangan pariwisata

(f) Masih kurangnya atraksi pada objek wisata yang dikelola oleh pemerintah

(g) Rendahnya kesadaran masyarakat untuk berpartisipasi dalam pengembangan pariwisata.

Kedua, Faktor Eksternal meliputi:

(a) Adanya kerja sama dengan pihak 
ketiga dalam pengembangan pariwisata seperti kerja sama dengan bandara dan komunitaskomunitas budaya

(b) Tersedianya akses transportasi untuk menuju ke Ternate dan objek wisata di Kota Ternate baik transportasi darat, laut, dan udara

(c) Adanya pemberdayaan masyarakat sekitar objek wisata yang dikelola oleh pemerintah daerah dengan menyediakan tempat warung makan tanpa dipungut retribusi oleh pemerintah

(d) Pemanfaatan teknologi sebagai sarana untuk mempromosikan dan mempermudah akses informasi terhadap pariwisata dengan pembangunan Ternate Information Center (TIC), serta media sosial dan website.

(e) Kurangnya kesadaran masyarakat untuk ikut dalam pemeliharaan terhadap objek wisata maupun sarana dan prasarana wisata yang dikelola oleh pemerintah

(f) Kondisi geografis Kota Ternate

(g) Banyaknya area publik dan objek wisata baru

(h) Masih minimnya daya tarik objek wisata yang dikelola oleh pemerintah.

3. Strategi yang sebaiknya dilakukan dalam rangka pengembangan pariwisata dalam peningkatan Pendapatan Asli Daerah Kota Ternate Provinsi Maluku Utara adalah:

(a) Mengoptimalkan fungsi dan program Dinas Pariwisata dalam pengembangan pariwisata

(b) Mengoptimalkan fungsi dan program Dinas Pariwisata dalam pengembangan pariwisata (c) Meningkatkan sarana dan prasarana pendukung pada objek wisata yang dikelola pemerintah

(d) Mengupayakan legalitas area publik atau objek wisata baru untuk dikelola oleh pemerintah daerah.

\section{SARAN}

Berdasarkan simpulan yang peneliti sampaikandiatas,makauntukpengembangan pariwisata dalam peningkatan Pendapatan Asli Daerah (PAD) dapat dilaksanakan dengan baik, maka kiranya peneliti dapat menyampaikan beberapa saran terkait hal tersebut, di antaranya adalah sebagai berikut.

1. Mengoptimalkan dimensi atraksi pada objek wisata yang dikelola oleh Pemerintah melalui Dinas Pariwisata Kota Ternate dengan menambahkan atraksi yang baru agar daya tarik pada objek wisata yang dikelola oleh pemerintah meningkat sehingga mendatangkan banyak wisatawan;

2. Dinas Pariwisata Kota Ternate dapat mengoptimalkan kemajuan teknologi yang selama ini sudah ada, untuk mempromosikan pariwisata Ternate kepada wisatawan baik wisatawan domestik maupun wisatawan mancanegara dengan cara yang menarik;

3. Dinas Pariwisata Kota Ternate sebaiknya berkenan melakukan studi banding dengan Dinas Pariwisata di Provinsi lain yang pengembangan pariwisatanya sudah maju dan terkenal. Bahkan sampai ke mancanegara.

\section{DAFTAR RUJUKAN}

Arikunto, Suharismi. 2010.Prosedur Penelitian. Jakarta: Rineka Cipta

Basrowi dan Suwandi. 2008. Memahami Penelitian Kualitatif. Jakarta: Rineka Cipta 
Bryson, J.M. 2016. Perencanaan Strategis Bagi Organisasi Sosial) diterjemahkan oleh M. Miftahuddin. Cet 9. Yogyakarta: Pustaka Pelajar

David, Fred R. 2010. Manajemen Strategis. Jakarta: Salemba Empat

Dirgantoro, Crow. 2001. Manajemen Strategis. Jakarta: Gramedia Widia Sarana

Grant, M Robert. 1999. Analisis Srtategi Kontemporer. Jakarta: Erlangga

Hunger, J. David and Wheelen, Thomas. 2009. Manajemen Strategis. Yogyakarta: Andi.

Kaiser, Charles. Dan Larry E. Helber. 1978. Tourism Planning \& Development. CBI. Pub

M. Suyanto. 2007. Marketing Strategy. Yogyakarta: Andi offset

Makmur. 2013. Teori Manajemen Strategis Dalam Pemerintahan dan Pembangunan. Bandung: Refika Aditama

Moleong, J. Lexy. 2011. Metodologi Penelitian Kualitatif. Bandung: Remaja Rosdakarya.

Nazir, Moh. 2011. Metode Penelitian. Bogor: Ghalia Indonesia

PB. Triton. 2011. Manajemen Strategi, Terapan Perusahaan dan Bisnis. Jakarta Selatan: Oriza

Pitana, I Gede. 2009. Pengantar Ilmu Pariwisata. Yogyakarta: Andi

Rangkuti, Freddy. 2016. Analisis SWOT Teknik Membedah Kasus Bisnis. Jakarta: Gramedia Pustaka Utama
Salusu, J. 2008. Pengambilan Keputusan Strategis, Untuk Organisasi Publik dan Organisasi Nonprofit. Jakarta: Grasindo

Sedarmayanti. 2013. Manajemen Sumber Daya Manusia. Bandung: Refika Aditama

Silalahi, Ulber. 2010. Metode Penelitian Sosial. Bandung: Refika Aditama

Spillane, James, J, 1987. Pariwisata Indonesia: Sejarah dan Prospeknya. Yogyakarta: Kanisius

Wahab, Salah, L.J Crampon, L.M Roth Field. 1997. Tourism Management. Jakarta: Pradnya Paramita

Yoeti, Oka A. 1997. Pengantar Ilmu Pariwisata. Bandung: Angkasa

\section{Peraturan Perundang-Undangan}

Undang-Undang No. 9 Tahun 1990 tentang Kepariwisataan

Undang-Undang No. 46 Tahun 1999 tentang Pemekaran Provinsi Maluku Utara

Undang-Undang No. 10 Tahun 2009 tentang Kepariwisataan

Undang-Undang No. 23 Tahun 2014 tentang Pemerintahan Daerah

Instruksi Presiden No. 9 Tahun 1969 tentang Pedoman Pengembangan Kepariwisataan Nasional

Peraturan Daerah Kota Ternate No. 11 Tahun 2009 tentang Rencana Induk Pengembangan Pariwisata Daerah. 
Visioner ! Vol. $13 \backslash$ No. 3\Desember 2021 